Your background

Your gender is:

$\square$ Male

$\square$ Female

Your age is:

$\square<30$ years

$\square 30$ - 40 years

$\square 40$ - 50 years

$\square 50$ - 60 years

$\square>60$ years

In which country are you living?

In which institution are you working?

This institution is a:

$\square$ Secondary referral center

$\square$ Tertiary referral center

$\square$ Other:

In your institution, who primarily manages pediatric achalasia?

$\square$ Pediatric surgeon

$\square$ Adult surgeon

$\square$ Pediatric gastroenterologist

$\square$ Adult gastroenterologist

$\square$ General pediatrician

$\square$ Patients with achalasia are referred to a tertiary unit

$\square$ Other:

In the last year, how many new cases of pediatric achalasia would you have seen in your institution? 
In your institution, are pediatric patients with achalasia discussed in a multidisciplinary setting?

$\square$ No (go to section 2)

$\square$ Yes

What disciplines are routinely involved in the care of pediatric achalasia patients in your institution? (you can choose more than one answer)?

$\square$ Pediatric gastroenterologist

$\square$ Gastroenterologist

$\square$ Surgeon

$\square$ Dietician

$\square$ Psychologist

$\square$ Psychiatrist

$\square$ Speech pathologist

$\square$ Radiologist

$\square$ Other:

In your institution, is there a protocol for the management of pediatric achalasia?

$\square$ Yes

$\square$ No

Is there an organized patient organization for pediatric patients with achalasia in your institution?

$\square$ Yes

$\square$ No

\section{Diagnosis of achalasia}

Which pre-procedure investigations do you perform in the work-up for the diagnosis of pediatric achalasia? (you can choose more than one option)

$\square$ Medical history taking and physical examination

$\square$ Eckardt score

$\square$ Blood draw

$\square$ A (timed) contrast swallow

$\square$ Isotope emptying study (radioactive meal)

$\square$ Conventional manometry

$\square$ High resolution manometry (HRM)

$\square$ High resolution impedance manometry (HRIM) 


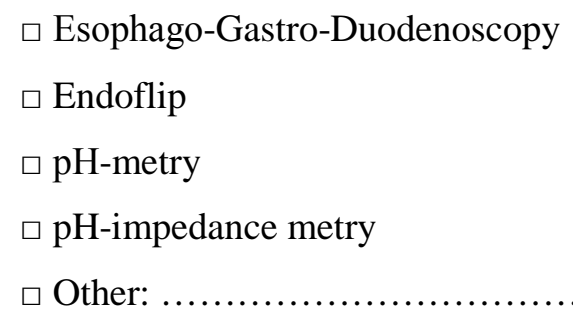

Please rank these 9 pre-procedure investigations for the diagnosis of pediatric achalasia in order of importance ( 1 being the most important, 9 being the least important):

\begin{tabular}{|c|c|c|c|c|c|c|c|c|}
\hline & $\begin{array}{l}\text { 1: most } \\
\text { important }\end{array}$ & 2 & 3 & 4 & 5 & 6 & 7 & 8 \\
\hline $\begin{array}{l}\text { Medical history taking and physical } \\
\text { examination }\end{array}$ & $\square$ & $\square$ & $\square$ & $\square$ & $\square$ & $\square$ & $\square$ & $\square$ \\
\hline Eckardt score & $\square$ & $\square$ & $\square$ & $\square$ & $\square$ & $\square$ & $\square$ & $\square$ \\
\hline Blood draw & $\square$ & $\square$ & $\square$ & $\square$ & $\square$ & $\square$ & $\square$ & $\square$ \\
\hline A (timed) contrast swallow & $\square$ & $\square$ & $\square$ & $\square$ & $\square$ & $\square$ & $\square$ & $\square$ \\
\hline Isotope emptying study (radioactive meal) & $\square$ & $\square$ & $\square$ & $\square$ & $\square$ & $\square$ & $\square$ & $\square$ \\
\hline Manometry (conventional or HR(I)M) & $\square$ & $\square$ & $\square$ & $\square$ & $\square$ & $\square$ & $\square$ & $\square$ \\
\hline Esophago-Gastro-Duodenoscopy & $\square$ & $\square$ & $\square$ & $\square$ & $\square$ & $\square$ & $\square$ & $\square$ \\
\hline EndoFlip & $\square$ & $\square$ & $\square$ & $\square$ & $\square$ & $\square$ & $\square$ & $\square$ \\
\hline pH-(impedance) metry & $\square$ & $\square$ & $\square$ & $\square$ & $\square$ & $\square$ & $\square$ & $\square$ \\
\hline
\end{tabular}

\section{Treatment of achalasia}

What is your primary treatment choice for pediatric achalasia?
$\square$ Medical therapy
$\square$ Botulinum toxin therapy
$\square$ Pneumatic balloon dilatation
$\square$ Heller's myotomy
$\square$ PerOral endoscopic myotomy (POEM)

Does patient age affect your treatment choice?

\section{Does Chicago Classification subtype affect your treatment choice?}

\footnotetext{
$\square$ Yes, I recommend treatment based on subtype

$\square$ No, I treat all subtypes the same (go to next section)
} 
$\square$ No, I do not perform high resolution manometry (go to next section)

For Type I, I recommend:

For Type II, I recommend:

For Type III, I recommend:

Botulinum toxin

Does your institution offer botulinum toxin therapy?

$\square$ No (go to next section)

$\square$ Yes

How many units of botox do you inject?

How do you choose the position of the injection(s)?

Pneumatic balloon dilatation

Does your institution offer pneumatic balloon dilatation?

$\square$ No (go to next section)

$\square$ Yes

What size of balloon do you start with in your average patients?

$\square 25 \mathrm{~mm}$

$\square 30 \mathrm{~mm}$

$\square 35 \mathrm{~mm}$

$\square 40 \mathrm{~mm}$

Does patient's age influence the size of the balloon you use?

$\square$ Yes, I use smaller balloons in younger children

$\square$ No, I always start with the same balloon size

What is the maximum size of balloon you use in children?

$\square 25 \mathrm{~mm}$
$\square 30 \mathrm{~mm}$ 

$\square 35 \mathrm{~mm}$
$\square 40 \mathrm{~mm}$
$\square$ other:

In your institution, initial treatment with pneumatic dilatation consists of:

$\square$ One dilatation

$\square$ Two dilatations, only when symptoms persist

$\square$ Two dilatations, regardless of symptoms

$\square$ other:

In your institution, pneumatic balloon dilatation is primarily performed by (you can choose more than one option):

$\square$ Pediatric gastroenterologist

$\square$ Adult gastroenterologist

$\square$ Pediatric surgeon

$\square$ Adult surgeon

$\square$ Intervention radiologist

$\square$ other:

Do you use fluoroscopic control?

$\square$ No

$\square$ Yes

If pneumatic dilatation is unsuccessful, after how many attempts do you consider offering/referring for surgery (not including the initial dilation/series of dilations)?

Is your choice affected by patient's age, if 'yes' please explain?

Is your choice affected by the duration of the time-period in which symptoms re-occur?

Is your choice affected by the achalasia subtype?

$\square$ Yes, I treat different subtypes differently

$\square$ No, I treat all subtypes the same (go to next section)

$\square$ No, I do not perform high resolution manometry (go to next section) 
For Type I, I recommend:

For Type II, I recommend:

For Type III, I recommend:

Heller's myotomy

Does your institution offer Heller's myotomy?

$\square$ No (go to next section)

$\square$ Yes

In your institution, is Heller's myotomy performed together with fundoplication?

$\square$ No

$\square$ Yes

$\square$ Dependent on the surgeon

In your institution, Heller's myotomy is primarily performed by:

$\square$ Adult surgeon

$\square$ Pediatric surgeon

$\square$ Adult and pediatric surgeon together

$\square$ other:

How many Heller's myotomies in children were performed in children in your institution in 2015 (only answer when exact numbers are available)?

How many Heller's myotomies in children were performed in children in your institution in 2016 (only answer when exact numbers are available)?

How many Heller's myotomies in children were performed in children in your institution in 2017 (only answer when exact numbers are available)?

Peroral endoscopic myotomy

Does your institution offer POEM?

$\square$ No

$\square$ Yes (skip next question)

What is/are the reason(s) that your institution does not offer POEM? (go to next section):

$\square$ Not enough good-quality studies on its efficacy and safety 
$\square$ Lack of expertise/training to perform POEM in our institution

$\square$ The risk of developing gastro-esophageal reflux disease

$\square$ other:

How many POEMs were performed in your institution in 2015 (only answer when exact numbers are available)?

How many POEMs were performed in your institution in 2016 (only answer when exact numbers are available)?

How many POEMs were performed in your institution in 2017 (only answer when exact numbers are available)?

In your institution, POEM is primarily performed by

$\square$ Adult surgeon

$\square$ Pediatric surgeon

$\square$ Adult gastroenterologist

$\square$ Pediatric gastroenterologist

$\square$ other:

Dianostic work-up and management of pediatric achalasia

What objective post-procedure assessments do you routinely perform in your institution (you can choose more than one option)?

\section{$\square$ Eckardt score}

$\square$ Quality of life scores

$\square$ A (timed) contrast swallow

$\square$ Isotope emptying study (radioactive meal)

$\square$ Conventional manometry

$\square$ High resolution manometry (HRM)

$\square$ High resolution impedance manometry (HRIM)

$\square$ Esophago-Gastro-Duodenoscopy

$\square$ pH-metry

$\square$ pH-impedance metry

$\square$ None

$\square$ other:

\section{Do you offer acid-suppressive therapy post-intervention?}

$\square$ Yes, standard to all patients

$\square$ Yes, but only standard to patients after Heller's myotomy or POEM

$\square$ Yes, but only when gastro-esophageal reflux symptoms are present

$\square$ Yes, but only when evidence of $\mathrm{pH}(\mathrm{MII})$-detected reflux or esophagitis

$\square$ No, never

$\square$ other: 
How long do you follow-up patients?

Which treatments would you consider for patients with recurrent symptoms after pneumatic balloon dilatation?
$\square$ Botox
$\square$ Repeat pneumatic balloon dilatation
$\square$ Heller's myotomy
$\square$ PerOral endoscopic myotomy (POEM)
$\square$ other:

Which treatments would you consider for patients with recurrent symptoms after Heller's myotomy?
$\square$ Botox
$\square$ Repeat pneumatic balloon dilatation
$\square$ Heller's myotomy
$\square$ PerOral endoscopic myotomy (POEM)
$\square$ other:

Which treatments would you considerfor patients with recurrent symptoms after POEM?
$\square$ Botox
$\square$ Repeat pneumatic balloon dilatation
$\square$ Heller's myotomy
$\square$ PerOral endoscopic myotomy (POEM)
$\square$ other:

\section{Remarks:}

